\title{
The Nutritional Value of Quality Protein Maize for Weaner Pigs
}

I.D.T. Mpofu ${ }^{1 *}$, S. Sibanda ${ }^{2}$, A. Shonihwa ${ }^{3}$ and Pixley ${ }^{4}$

${ }^{1}$ University of Namibia, Namibia

${ }^{2}$ University of Zimbabwe, Animal Science Department, Zimbabwe

${ }^{3}$ Pig Industry Board Acturus, Zimbabwe

${ }^{4}$ CIMMYT, International Maize and Wheat Improvement Center, Zimbabwe

\begin{abstract}
This study was done to find out the potential and efficacy of Quality Protein Maize (QPM) as a substitute for normal maize variety in intensive pig production in an attempt to reduce the cost of production. Thirty-two weaner pigs were assigned to four treatment groups in a completely randomized block design with a $2 \times 2$ factorial arrangement of treatments. Blocking was done on initial weight and sex. The treatments were a high inclusion rate of both QPM and normal maize at $72.3 \%$ inclusion rate compared to a low inclusion rate of $64.3 \%$ in both cases. Water and feed was provided ad-libitum throughout the study period. Feed intake, water consumption, weight gain and mortality were recorded. Feed intake was more $(P<0.05)$ in animals fed $72.3 \%$ ordinary maize compared to the other diets. High QPM diet had the highest $(\mathrm{P}<0.05)$ feed conversion efficiency and was cheaper because less protein source (soyabean meal) was included. The diet by sex interaction was not significant $(P>0.05)$. The results indicated that feeding QPM to weaner pigs at a higher level of $72.3 \%$ inclusion level could command a higher food conversion efficiency and at a reduced cost of production.
\end{abstract}

Keywords: Quality protein maize; Essential amino acids; Pig weaner diets

\section{Introduction}

The high consumption of maize by the human population in a number of countries in Latin America and Africa and the wellestablished lysine and tryptophan deficiencies in maize protein motivated the search for a maize kernel with higher concentrations of these essential amino acids in its protein. The possibility of finding better varieties of maize appeared feasible on the basis of three facts. One was that by selection, oil content in the maize kernel could be increased from about 4 to 15 percent. This increase was obtained by increasing the size of the germ, the part of the kernel where the oil is concentrated. The same researchers showed that it was possible to increase total protein content from about 6 to 18 percent by increasing the prolamine (zein) fraction in maize endosperm. The third finding was the wide variability in lysine content reported among varieties and selections of maize.

According to de Groote, Nyanamba, and Wahome, Quality Protein Maize (QPM) has increased levels of lysine and tryptophan. These are limiting amino acids for monogastric animals, so the use of QPM in animal feed has a potential to reduce the need for more expensive high-protein sources like soyabean meal [1]. These authors, in Kenya, through the application of a linear programming optimization model with the composition and prices of feed components, obtained a 5\% cost reduction by substituting QPM for regular maize in poultry feed. Economic evaluation from this study showed that if QPM were to substitute regular maize in broiler feed in Kenya, this $5 \%$ cost reduction would translate into a poultry industry - wide gain of US $\$ 300,000$. This is a very significant saving especially for developing countries.

Maize plays a very important role in both animal and human nutrition in Africa. It is the principal energy source in pig diets. Although, maize has a high calorific value, its protein content is low $(8-9 \%)$ and it is deficient in two essential amino acids namely, lysine and tryptophan. Lysine is the most limiting amino acid in maize for pig feeding [2]. This situation calls for expensive supplementation using commercial grade amino acids especially when feeding weaners.
The potential of high-lysine maize in alleviating malnutrition in the developing world has not been realized because the performance of these maize varieties in indigenous foods of these regions is poor. QPM, an improvement of the soft kernel high lysine maize has been developed and was first discovered in 1963 and improved by breeders in the early 1980's. QPM promises to have improved nutritional value and also promises to be a vehicle for cost savings for everything from infant formula to corn chips and animal feed. Moreover, QPM looks, tastes, and yields like normal maize, but has nearly twice the levels of lysine and tryptophan [3]. QPM was developed using conventional breeding. To date QPM cultivars have been released in 22 developing countries. Releases in 18 of those countries have occurred since 1997 , when CIMMYT began intensive testing and promotion of QPM with funding from the Nippon Foundation. Vasal and former CIMMYT cereal chemist, Dr. Evangelina Villegas, shared the 2000 World Food Prize for their successful work during the 1970s and 80s to develop QPM. Its only disadvantage is that it is more susceptible to mild dew disease and maize streak virus [4].

A study elsewhere has indicated that QPM can command 29.8\% more daily weight gain in pigs compared to ordinary maize [5]. The use of QPM in pig weaner diets has a potential of reducing feed costs without negatively affecting the quality of the total feed. Newly weaned piglets require higher levels of lysine than growers and finishers and could therefore, benefit more from QPM inclusion in feed formulations. Some work has also shown that a serving on fishmeal to the tune of $22 \%$ can be achieved when QPM is fed to pigs [4].

${ }^{*}$ Corresponding author: I.D.T Mpofu, University of Namibia P/Bag 13301 Windhoek, Namibia, E-mail: impofu66@yahoo.com

Received July 29, 2012; Accepted August 17, 2012; Published August 25, 2012

Citation: Mpofu IDT, Sibanda S, Shonihwa A, Pixley (2012) The Nutritional Value of Quality Protein Maize for Weaner Pigs. J Pet Environ Biotechnol 3:129. doi:10.4172/2157-7463.1000129

Copyright: (C) 2012 Mpofu IDT, et al. This is an open-access article distributed under the terms of the Creative Commons Attribution License, which permits unrestricted use, distribution, and reproduction in any medium, provided the original author and source are credited. 
The specific objectives of this study were:

- To evaluate the performance of the newly weaned piglets fed diets containing high and low levels of QPM in tandem with high and low levels of ordinary maize.

- To evaluate the economic benefits of using QPM instead of ordinary maize in weaner rations

\section{Materials and Methods}

\section{Site}

The experiment was carried out at the Pig Industry Board (PIB) pig farm in Acturus, located $26 \mathrm{~km}$ East of the capital city of Zimbabwe called Harare. The area is located in Agricultural Natural Region 1a, which receives an average rainfall of 700-1050 mm/year.

\section{The animals}

The breed that was used in the experiment was a cross between Large White and the Landrace. Ear notching was used to identify the animals. The age of the weaner piglets used was five weeks. The animals were balanced for sex in each pen. The animals were regularly checked for any disease outbreak and treated accordingly.

\section{Treatments and the experimental procedure}

The study consisted of four diets. Each of the diets was replicated four times. A total of 32 weaners were used with two weaners housed per pen hence each pen was an experimental unit. Blocking was done on initial weight and sex. The experimental design that was used to collect the data was a completely randomized block design (CRBD) with a $2 \times 2$ factorial arrangement of treatments. Pigs were given adlibitum access to feed and water. Growth rate and feed intake were measured weekly. Table 1 shows the ingredients used that defined the treatments that were used.

\section{Management of experimental animals and data collection}

The pigs were initially fed for 21 days with the feeds under test to accustom the pigs to the experimental environment and to remove residues of previously fed feeds from their digestive tract. There after the pigs were fed for another three weeks for data gathering. The pigs were all de-wormed before the experiment commenced. Proper sanitary conditions were maintained throughout the experiment to prevent experimental noise from disease outbreak. Initial weights were taken at the start of the experiment. Feed intake, weight gain, feed efficiency (as Feed Conversion Ratio (FCR)), water consumption, mortality rate; costs per $100 \mathrm{~kg}$ feed were recorded. The pigs were weighed at the end of the experiment to get the final live weights.

The rations were as follows:

Treatment 1: Low inclusion rate of Ordinary Maize at $64.3 \%$ inclusion rate.

Treatment 2: Low inclusion rate of Quality Protein Maize at 64.3\% inclusion rate.

Treatment 3: High inclusion rate of Ordinary Maize at $72.3 \%$ inclusion rate.

Treatment 4: High inclusion rate of Quality Protein Maize at 72.3\% inclusion rate.

Diet $\mathrm{A}$ is the Pig Industry Board weaner diet. In Diets B and D quality protein maize was added in place of ordinary maize at low and high inclusion rates respectively. In diet A and C, ordinary maize was used at low and high inclusion rate respectively. All the four diets had equal proportions of limestone flour, DBI (mineral and vitamin mix), TSP (antibiotic) and monocalcium phosphate.

\section{Statistical analysis}

The following statistical model was used for data analysis

Yijk $=\mu+\mathrm{T}_{\mathrm{i}}+\mathrm{B}_{\mathrm{j}}+\mathrm{b}_{1(\mathrm{inwt})}+\mathrm{E}_{\mathrm{ijk}}$

Where $\mu$ is the constant mean common to all observations;

$\mathrm{T}_{\mathrm{i}}$ is the effect due to the diets

$B_{j}$ is the effect due to the sexes

$\left.B_{1 \text { (inwt }}\right)$ is the linear regression coefficient of initial weight on gain

$\mathrm{E}_{\mathrm{ijk}}$ is the random residual error

$\mathrm{Y}_{\mathrm{ijk}}$ is the dependant variable i.e. either gain or feed intake

The data was analyzed using the SAS General Linear Model procedures (1998) [6].

\section{Cost of the feeds}

The following market prices in Zimbabwean Dollars were used in the economic analysis.
Ordinary Maize
ZW $\$ 4200.00 /$ tonne
Quality Protein maize
ZW $\$ 4200.00 /$ tonne
Soyabean meal
ZW\$380/50 kg bag

The costs of other additives were constant across all the diets.

\section{Results}

Table 2 shows the results that were obtained when the four diets were chemically analyzed using the conventional proximate analysis method. The parameters that were being investigated were the contents of dry matter, ash, phosphorus (Pho), calcium content (Ca), ether extract (EE), Acid Detergent Fibre (ADF), Neutral Detergent Fibre (NDF) and crude protein (CP). These analyses gave an opportunity of finding out if the diets met the basic needs of the animals. The table 2 shows that the four diets had apparently similar DM \%. Diet B had the highest crude protein percentage and diet $\mathrm{C}$ had the lowest. Diet $\mathrm{A}$ had the highest NDF value compared to the rest of the diets. The calcium and phosphorus ratios (Ca:P) were apparently similar in all the diets that is $1: 1$.

Table 3 shows the apparent amount of feed that was consumed over the whole feeding trial. Feed intake was more in animals fed Diet $\mathrm{C}$ (higher level of ordinary maize) as compared to the other diets. The basic trend across the three weeks was that there was an increase in feed

\begin{tabular}{|l|l|l|l|l|}
\hline & Diet A & Diet B & Diet C & Diet D \\
\hline Ordinary maize & 64.3 & - & 72.3 & - \\
\hline OPM & - & 64.3 & - & 72.3 \\
\hline Soyabean meal & 31.0 & 31.0 & 23.0 & 23.0 \\
\hline Limestone flour & 1.5 & 1.5 & 1.5 & 1.5 \\
\hline $\begin{array}{l}\text { Monocalcium } \\
\text { Phosphate }\end{array}$ & 2.0 & 2.0 & 2.0 & 2.0 \\
\hline DBI & 1.0 & 1.0 & 1.0 & 1.0 \\
\hline TSP & 0.2 & 0.2 & 0.2 & 0.2 \\
\hline
\end{tabular}

Table 1: Ingredient composition (\%) of the diets used in the study. 


\begin{tabular}{|c|c|c|c|c|c|c|c|c|}
\hline DM\% & Diet & EE\% & CP\% & NDF\% & ADF\% & Ash\% & $\mathrm{Ca} \%$ & Pho\% \\
\hline $\begin{array}{l}90.15 \\
88.95 \\
89.11 \\
88.5\end{array}$ & $\begin{array}{l}A \\
B \\
C \\
D\end{array}$ & $\begin{array}{l}1.62 \\
1.82 \\
1.27 \\
1.21\end{array}$ & $\begin{array}{l}16.3 \\
16.8 \\
15.2 \\
15.7\end{array}$ & $\begin{array}{l}26.6 \\
25.6 \\
23.1 \\
23.3\end{array}$ & $\begin{array}{l}4.7 \\
4.9 \\
2.80 \\
3.92\end{array}$ & $\begin{array}{l}8.1 \\
7.25 \\
6.75 \\
6.1\end{array}$ & $\begin{array}{l}0.800 \\
0.824 \\
0.550 \\
0.600\end{array}$ & $\begin{array}{l}0.750 \\
0.762 \\
0.500 \\
0.565\end{array}$ \\
\hline
\end{tabular}

Table 2: Proximate analysis of the diets.

\begin{tabular}{|l|l|l|l|l|}
\hline & & \multicolumn{3}{l}{ Diets/kg } \\
\hline Week & Low Ordinary Maize & Low QPM & High Ordinary Maize \\
\hline 1 & 0.85 & 0.84 & 1.08 & 1.08 \\
2 & 1.0 & 0.95 & 1.48 & 0.87 \\
3 & 1.6 & 1.56 & 3.98 & 1.31 \\
\hline Total feed intake/kg/pig DM & 3.45 & 3.35 & 3.64 \\
\hline
\end{tabular}

Table 3: Average feed intake $(\mathrm{kg})$ per pig over the whole feeding trial period.

\begin{tabular}{|l|l|l|l|l|}
\hline & & & Diets \\
\hline Week & A & B & C & D \\
\hline Cost/100kg feed & ZW\$505.66 & ZW\$505.66 & 4.87 \\
\hline FCR & 3.88 & 4.65 & ZW $\$ 478.46$ \\
\hline Average Weaner Weight Gain over 21 days & 0.89 & 0.72 & 0.75 \\
\hline
\end{tabular}

Table 4: Cost benefit analysis, Feed Conversion Ratio \& Mean gain/week of the piglets.

intake with time.

There was no significant difference $(\mathrm{P}>0.05)$ in the overall increase in the weight gains across all diets.

Table 4 shows the economic analysis, feed conversion efficiency (measured as Feed Conversion Ratio (FCR)) and the mean gain in weight of each pig over the 21 day data collection period.

Feed conversion ratio is the amount of feed (DM basis) that is needed to increase the weight of the animal by a kilogram. When these values were calculated it was noted that piglets fed Diet A and D had apparently similar FCR. High QPM, Diet D, had high $(\mathrm{P}<0.05)$ feed efficiency (low FCR) and yet cheaper because less protein source (soybean meal) was included.

\section{Discussion}

\section{Quality of the diet in relation to FCR}

From Table 2, the CP contents of the diets were generally lower than the usual commercial diets for weaners which must be about 17 to $18 \%$. However the low QPM diet had a CP content of 16.8 compared to the low ordinary maize diet of $16.3 \%$ mainly because of the better quality of protein due to higher levels of limiting amino acids from the QPM. The high QPM diet when compared to the high ordinary maize had slightly higher CP content also due to the better amino acid profile in this diets contributed by QPM.

\section{Feed intake in relation to weight gain}

Feed intake significantly affected weight gain $(\mathrm{P}<0.05)$. From Table 3 it can be seen that the total apparent feed intake of the diets differed. Weaners fed on high ordinary maize had higher feed intake than high QPM yet the later had higher weight gains. The lower intake of weaners fed high QPM diet could have been due to the high NDF value of $26.7 \%$, which might have affected the palatability of the diet. NRC (1998) reports that high crude fiber content can affect the palatability of a diet [7]. What is significant is that although the high QPM diet commanded less intake it effected higher weight gains. The basic trend across the diets was that there was an increase in feed intake with time. According to Campbell and Dunkin [8] it was reported that there would be an increase in feed intake linearly post weaning.
In this trial the animals were allowed to consume feed and water ad-libitum, therefore several factors could also have affected or contributed to the difference in feed intake. According to Owen and Ridgeman, the energy component of the diet will affect the amount of feed consumed by either decreasing or increasing it in order to meet the requirements of the body [9]. This can then explain the high feed intake for Diet C (high ordinary maize inclusion).

\section{Sex and diet independent effect on weight gain}

The diet by sex interaction was not significant $(\mathrm{P}>0.05)$. This means that the increase in weight gain between the piglets was not due to their differences in sex. In other studies carried out by Campbell and Dunkin it was found that sex had little or no effect on the rate of protein deposition, which is gain in muscle tissue in weaners [8].

\section{Cost benefit analysis}

From the calculations (Table 4) Diet C and D had the same cost per $100 \mathrm{~kg}$ of feed and lower compared to diet A and B. Conclusively we can say that the conventional Diet A (the PIB weaner diet) could be replaced by Diet $\mathrm{D}$ that is much cheaper to formulate and can still give the same FCR. In a related study Omage et al. [10] indicated that feeding QPM to rabbits without lysine supplementation could sustain rabbits without affecting their performance, health at a reduced cost of production.

\section{Conclusion and Recommendations}

When comparing the FCRs it can be noted that animals fed Diet A (low ordinary maize inclusion level) and Diet D (high QPM inclusion level) could convert feed into tissue with the same efficiency. This means there is an advantage in using QPM in the diets of weaner pigs as lower levels of the expensive soyabean meal can then be used.

From the calculations for the cost of the feeds, Diets D (high QPM inclusion level) was cheaper than Diet A (ordinary maize). Therefore it would be ideal to replace the Pig Industry Board weaner Diet A (low ordinary maize level) with Diet D (high QPM inclusion level).

\section{References}

1. De Groote H, Nyanamba T, Wahome R (2010) Quality protein maize for the 
Citation: Mpofu IDT, Sibanda S, Shonihwa A, Pixley (2012) The Nutritional Value of Quality Protein Maize for Weaner Pigs. J Pet Environ Biotechnol 3:129. doi:10.4172/2157-7463.1000129

feed industry in Kenya. Outlook on Agriculture 39: 291-298.

2. Beeson MWM (1966) Nutritional value of high-lysine maize. Proc Distillers Feed Research Council 21: 70

3. Cristinia M, Bicardo HM (1994) Nutritional perspective of QPM. International Symposium on QPM, Dec 1-3 Sete Lagoas, MG Brazil pp 67.

4. Villegas E (1994) Factors limiting QPM development and utilization. International Symposium on QPM, Dec 1-3 Sete Lagoas, MG Brazil pp 73-75.

5. De-Quan S, Shi-Huang Z (1994) Maize production and QPM breeding program in China. International Symposium on QPM. December 1-3 Sete Lagoas, MG Brazil pp 238-239.

6. SAS (1998) Statistical Analysis System. Procedures for Linear Models.
7. National Research Council (1998) Nutrient requirement of swine, tenth revised edition. National Academies Press, 2101 Constitution Avenue NW. Lockbox 285, Washington D.C.

8. Campbell RG, Dunkin AC (1983) The influence of nutrition in early life on growth and development of the pig 3. Effects of energy intake prior and subsequent to $10 \mathrm{~kg}$ on growth and development to $30 \mathrm{~kg}$ live weight. Journal of Nutrition 36: 435-443.

9. Owen JB, Ridgeman WJ (1967) The effect of dietary energy content on the voluntary intake of pigs. Animal Prod 9: 107-113.

10. Omage JJ, Agubosi OCP, Bawa GS, Onimisi PA (2009) Evaluation of the nutritive value of quality protein maize on the growth performance and carcass characteristics of weaner rabbits. Pakistan Journal of Nutrition 8: 106-111. 